Acta vet. scand. 1976, 17, 178-189.

From the Department of Surgery and the Department of Clinical Biochemistry, Royal Veterinary College, Stockholm, Sweden.

\title{
LDH AND LDH ISOENZYMES OF SYNOVIAL FLUID IN THE HORSE*
}

\author{
By \\ Sven Rejnö
}

\begin{abstract}
REJNö, S.: $L D H$ and $L D H$ isoenzymes of synovial fluid in the horse. Acta vet. scand. 1976, 17, 178-189. - LDH is an intracellular enzyme, which when cells degenerate is released to the extracellular spaces and body fluids. Cells and organs in the mammalian body differ from each other with respect to their LDH isoenzyme patterns. These circumstances have led to the use of $\mathrm{LDH}$ isoenzyme determinations in laboratory diagnostic work. In the present investigation total $L D H$ activity and $L D H$ isoenzyme distribution in equine synovial fluid from healthy joints, joints with serous arthritis, osteochondrosis dissecans and arthrosis, were determined. The fluids from the diseased joints differed from normal synovial fluid with respect to total LDH activity, and the different joint diseases each seemed to give rise to a characteristic isoenzyme pattern. In order to examine possible sources of the increased $\mathrm{LDH}$ activity and altered isoenzyme patterns, blood plasma, red and white blood cells, synovial membrane and articular cartilage were also studied. It was found that $\mathrm{LDH}_{4}$ and $\mathrm{LDH}_{5}$ were present in high amounts in articular cartilage, and an increase in these isoenzymes was the most characteristic feature in synovial fluid from joints with arthrosis. The results were discussed in view of possible diagnostic value of isoenzyme determinations on synovial fluid.
\end{abstract}

LDH; isoenzymes; synovial fluid; joint disease; horse.

"Lactic dehydrogenase (LDH) is an enzyme that reversibly catalyzes the reduction of pyruvate to lactate in the presence of nicotinamide dinucleotide (NAD) as co-factor. This process is known to occur in all cells exhibiting glycolytic activity, thus explaining the ubiquitous distribution of this enzyme in the

* This investigation was supported by grants from professor Gerhard Forssell's stipendiefond, H. C. Lagers stipendiefond, Sveriges Veterinärförbunds forskningsfond, Virginska fonden, Jordbrukets försäkringsbolag and Anslaget för främjande av ograduerade forskares vetenskapliga verksamhet. 
body" (cit. Hyldgaard-Jensen 1971). The term isoenzyme has been recommended to describe the different molecular forms in which proteins may exist with the same enzymatic specificity. Using different fractionating techniques, e.g. agarose-gel electrophoresis, it has been found that mammalian sera and many organs contain up to five protein fractions with LDH activity, LDH isoenzymes. The LDH isoenzymes have been numbered differently by European and American workers. The nomenclature used in this paper was proposed by the Subcommittee on Isoenzymes of the International Union of Biochemistry. The five molecular forms of $\mathrm{LDH}$ are designated $\mathrm{LDH}_{1}, \mathrm{LDH}_{2}, \mathrm{LDH}_{3}$, $\mathrm{LDH}_{4}$ and $\mathrm{LDH}_{5}$ according to their arrangement in order of decreasing mobility during electrophoresis. The isoenzyme migrating fastest toward the anode is $\mathbf{L D H}_{1} . \mathrm{LDH}_{1}$ and $\mathrm{LDH}_{5}$ have been proposed to be extreme forms and $\mathrm{LDH}_{2}, \mathrm{LDH}_{3}$ and $\mathrm{LDH}_{4}$ to be intermediate forms, not only in electrophoretic mobility, but also in e.g. amino acid content (i.a. Henry et al. 1974). It has been suggested that $\mathrm{LDH}_{1}$ dominates in tissues and cells with aerobic metabolism, while $\mathrm{LDH}_{5}$ is important for anaerobic glycolysis. Electrophoretic studies of LDH isoenzymes have shown that the five isoenzymes are distributed differently in various organs and tissues of the mammalian body.

LDH is thought to be produced within the cells and has been regarded as a predominantly cytoplasmic enzyme. It is also present in extracellular body fluids, such as blood plasma and synovial fluid. Under conditions during which cell membrane permeability is changed or cells are degenerating, enzymes are thought to be released to the extracellular space. Thus a damage of an organ or tissue could be reflected in the enzyme- and isoenzyme pattern of the body fluid involved. LDH and especially LDH isoenzyme determinations have thus been shown to be of importance as an aid in the clinical diagnosis of certain diseases, such as myocardial infarction and hepatic necrosis in man.

In the last decade several reports have been presented on LDH and LDH isoenzymes in arthritic synovial fluid. The majority of reports were based on human material. Vesell et al. (1962), Cohen (1964), Alexandersson et al. (1968), Veys \& Wieme (1968), Lindy et al. (1971) and Wegner \& Mühlback (1971) compared synovial fluids of different joint diseases as well as synovial fluid and blood serum from patients with joint diseases. Barthel et al. (1971) reported changes in the LDH isoenzyme 
pattern of synovial fluid from swine infected with Mycoplasma hyorhinis. So far no investigation on LDH and LDH isoenzymes of horse synovial fluid seems to be present in the available literature.

In thoroughbred and standardbred race horses joint lesions are common. It is thought that many lesions are caused by minor traumata during training and racing. For adequate therapy and correct prognosis it is essential to understand the underlying pathology. In orthopaedic horse practice improved diagnostic procedures and techniques are therefore required.

The aim of the present paper was to study LDH activity and LDH isoenzyme distribution in synovial fluid from normal and diseased equine joints. In order to determine the sources of synovial LDH, tissue extracts of synovial membrane, articular cartilage, red and white blood cells and plasma were also examined.

\section{MATERIAL AND METHODS}

The animals from which synovial fluid was taken are presented in Table 1, which gives breed, sex, age and joint from which the sample was obtained. Synovial fluid was taken from 39 joints of 25 horses. Twenty-one of the horses were standardbred trotters, one was a thoroughbred, one was a crossbred riding pony, one was a Connemara pony and one was a Swedish halfbred horse. The ages varied from 0.5 to eight years, mean age being 3.5 years. Nine horses were female, four were geldings and $\mathbf{1 0}$ were stallions. The criteria for clinically healthy joints, chosen as controls, were:

a) The horse exhibited no sign of general disease.

b) No factor causative of lameness could be ascribed to the joint.

c) The joint exhibited normal range of motion.

d) No swelling, tenderness or heat could be noticed over the joint.

e) The joint capsule was felt to be of normal thickness and elasticity on palpation.

f) The joint exhibited no noticeable increase of synovial fluid on palpation.

The criteria for the diagnosis of osteochondrosis dissecans (OD) were:

a) Marked to severe increase of synovial fluid.

b) Typical changes in the articular cartilage and in the subchondral bone of the diseased joint on radiographic examination (Strömberg \& Rejnö, in press). 
Lameness ascribed to the joint was frequent but not consistent (Strömberg \& Rejnö, in press). In seven joints with OD in this material the diagnosis was confirmed at necropsy or at arthrotomy for surgical treatment of the joint lesion. The remaining horses with OD were neither slaughtered nor treated surgically.

The criteria for the diagnosis of serous arthritis were:

a) Moderate increase of the synovial fluid in the joint.

b) Lameness caused by pain from the joint. This was confirmed by intraarticular anesthesia.

c) No radiographic findings in the joint.

The criteria for the diagnosis of arthrosis were:

a) Thickening and decreased elasticity of the joint capsule.

b) Decreased range of motion of the joint.

c) Lameness caused by pain from the joint. This was confirmed by intraarticular anesthesia.

d) Periarticular and marginal osteophytes and in some cases sclerosis of the subchondral bone seen on radiographic examination.

\section{Synovial fluid}

Immediately after aspiration of synovial fluid from the joints the samples were centrifuged. The cell-free supernatants were treated with hyaluronidase for $30 \mathrm{~min}$. before analyses were performed.

\section{Synovial membrane and articular cartilage}

Synovial membrane and articular cartilage were obtained under general anesthesia (Fluothane- $\mathrm{N}_{2} \mathrm{O}-\mathrm{O}_{2}$ ) from six healthy joints (criteria: see above) of three horses. After thorough washing in isotonic $\mathrm{NaCl}$-solution approx. $1 \mathrm{~g}$ of each tissue was homogenized in an Ultra-Turrax homogenizer (Janke \& Kunkel, K.G., Staufen/Breisgau, Western Germany) and placed in a freezer at $-20^{\circ} \mathrm{C}$ for $10 \mathrm{~min}$. before thawing and centrifugation. Analyses of the supernatants were then performed.

\section{Blood cells and plasma}

Red and white blood cells were obtained from heparinized blood samples from four horses without any clinical signs of disease. After separation of the blood cells by autosedimentation 
they were thoroughly washed in isotonic NaCl-solution. Thereafter they were placed in $5 \mathrm{ml}$ of aq. dest. in a freezer at $-20^{\circ} \mathrm{C}$ for $10 \mathrm{~min}$. After thawing they were centrifuged and the supernatants were analyzed. Plasma from the same blood samples was analyzed in two cases. Due to these time consuming procedures tissue- and cell extracts were analysed the day after sampling though always within $20 \mathrm{hrs}$. after sampling. In the meantime they were stored at room temperature.

Total LDH activity was determined with a LKB 8600 Reaction Rate Analyzer by the method recommended by the Scandinavian Committee on Enzymes (1974). The reagents were provided by AB Kabi, Stockholm. LDH isoenzymes were separated with electrophoresis in $1 \%$ agarose-gel for $75 \mathrm{~min}$. and at a voltage of 10 $\mathrm{v} / \mathrm{cm}$. The water of the cooling system in the electrophoresis equipment had a constant temperature of $10^{\circ} \mathrm{C}$. The electrode buffer was veronal buffer $0.024 \mathrm{M}, \mathrm{pH} \mathrm{8.6}$, and the agarose was prepared in the same buffer. As electrodes five layers of filter paper (Whatman No. 1) were used. The plates were stained for LDH activity with Nitro BT according to the method of Wieme (1965).

The total numbers of white blood cells (WBC) in the synovial fluids were determined by using a hemocytometer (Bürker chamber) after dilution $1: 5$ in isotonic NaCl-solution with added heparin. Staining was done with gentian violet.

\section{RESULTS}

$\mathrm{S}$ y $\mathrm{n}$ ovi a $\mathbf{l} \mathrm{m} \mathrm{e} \mathrm{m}$ b $\mathrm{r}$ a $\mathrm{n}$ e from the equine joints examined, contained mainly $\mathrm{LDH}_{2}, \mathrm{LDH}_{3}$ and $\mathrm{LDH}_{4}$ and in two samples a small amount of $\mathrm{LDH}_{5}$ (Fig. 1, Table 3).

Articular cartilage contained mainly $\mathrm{LDH}_{3}, \mathrm{LDH}_{4}$ and $\mathrm{LDH}_{5} ; \mathrm{LDH}_{4}$ being the most intensely stained isoenzyme (Fig. 1, Table 3).

The erythrocytes in the present material contained exclusively $\mathrm{LDH}_{1}$ and $\mathrm{LDH}_{2}$ and $\mathrm{the}$ white blood cells contained $\mathrm{LDH}_{2}, \mathrm{LDH}_{3}, \mathrm{LDH}_{4}$ and $\mathrm{LDH}_{5}$ (Fig. 1, Table 3 ).

Sy novial f l u id from the clinically healthy joints (control group) had a mean total LDH activity of $88 \mathrm{u} / 1$ (range 50-109). When fractionating the $\mathrm{LDH}$ isoenzymes of synovial fluid from the healthy joints, $\mathrm{LDH}$ activity was found to consist of 


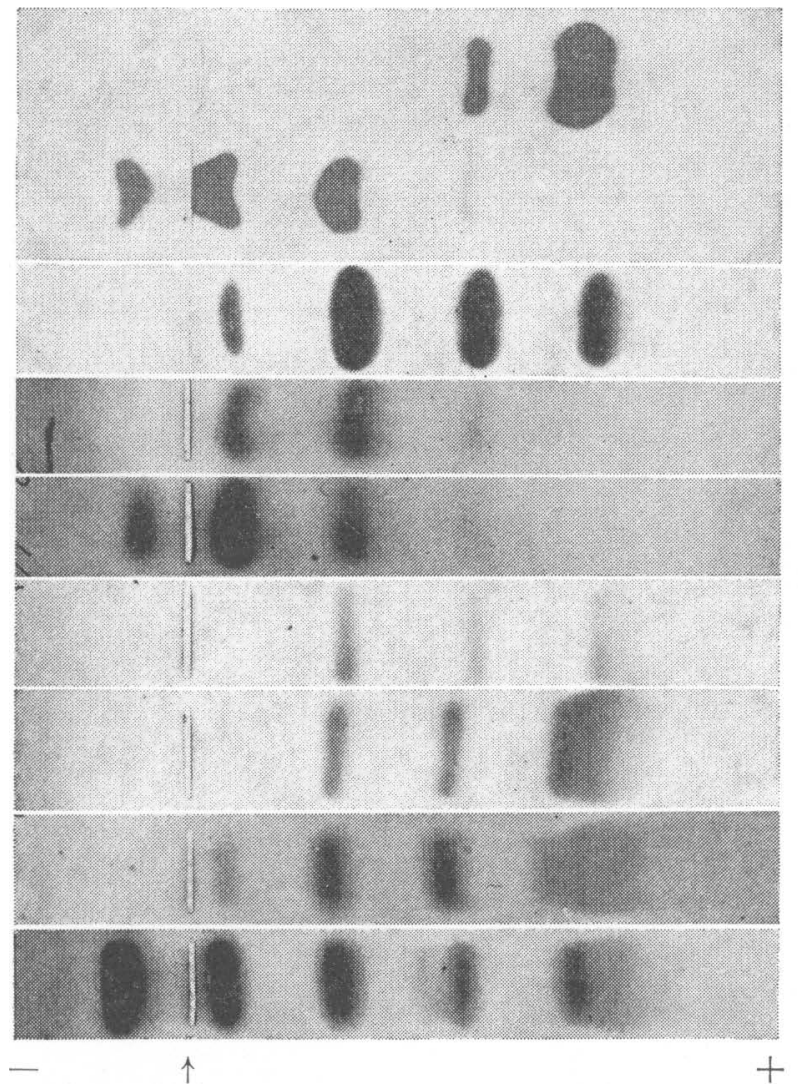

Red blood cells

White blood cells

Blood plasma

Synovial membrane

Articular cartilage

Synovial fluid, normal joints

Synovial fluid, serous arthrit

Synovial fluid, osteochondrosi

Synovial fluid, arthrosis

F i g u re 1. Zymograms of LDH isoenzymes in synovial membrane, articular cartilage, blood plasma, RBC, WBC, and in synovial fluids from normal joints and joints with serous arthritis, osteochondrosis dissecans and arthrosis are shown. Arrow indicates application growe. $+=$ anode. $-=$ kathode.

$\mathrm{LDH}_{1}, \mathrm{LDH}_{2}$ and $\mathrm{LDH}_{3}$ and to a small extent of $\mathrm{LDH}_{4}$ (Fig. 1). The total LDH activity of synovial fluid was increased in the different joint lesions and the LDH isoenzyme pattern showed some alterations. In conjunction with so called s e rous ar$t h r i t i s$, which is mainly constituted by synovitis, there were only small changes in the isoenzyme pattern. There was an increase in total LDH activity (mean $292 \mathrm{u} / \mathrm{l}$, range $152-667$ ), and the isoenzymes of normal synovial fluid were again recorded but were more deeply stained (Fig. 1, Table 2), indicating that $\mathrm{LDH}_{1}$, $\mathrm{LDH}_{2}, \mathrm{LDH}_{3}$ and $\mathrm{LDH}_{4}$ components were increased. 
Table 1. The breed-, age- and sex distribution of the animals in the different groups of joints is presented. Abbreviations: st.br. = standardbred, h.br. = halfbred, th.br. = thoroughbred, con.pony = Connemara pony, cr.pony $=$ crossbred riding pony, $\mathrm{m}=$ stallions and geldings.

\begin{tabular}{|c|c|c|c|c|c|}
\hline \multirow{2}{*}{ Group of joints } & \multirow{2}{*}{$\begin{array}{l}\text { Number of } \\
\text { joints }\end{array}$} & \multicolumn{4}{|c|}{ Horses } \\
\hline & & number & breed & age & $\operatorname{sex}$ \\
\hline \multirow[t]{2}{*}{ Healthy joints } & 6 tibiotarsal & 11 & 7 st.br. & $3-8$ yrs & $\begin{array}{l}3 \mathrm{~m} \\
4 \mathrm{f}\end{array}$ \\
\hline & 5 carpal & & 4 h.br. & $4-12$ yrs & $4 \mathrm{~m}$ \\
\hline \multirow{2}{*}{$\begin{array}{l}\text { Joints with } \\
\text { serous arthritis }\end{array}$} & 9 carpal & 7 & 6 st.br. & $2-8$ yrs & $\begin{array}{l}4 \mathrm{~m} \\
2 \mathrm{f}\end{array}$ \\
\hline & $\begin{array}{l}3 \text { femorotibial } \\
1 \text { phalangeal }\end{array}$ & & 1 h.br. & $4 \mathrm{yrs}$ & $\mathrm{m}$ \\
\hline \multirow{3}{*}{$\begin{array}{l}\text { Joints with } \\
\text { osteochondrosis } \\
\text { dissecans }\end{array}$} & 6 tibiotarsal & 8 & 1 th.br. & $11 / 2 \mathrm{yr}$ & m \\
\hline & 5 femoropatellar & & 6 st.br. & $1 / 2-4$ yrs & $<_{2 \mathrm{f}}$ \\
\hline & & & 1 con.pony & $1 \mathrm{yr}$ & m \\
\hline \multirow{2}{*}{$\begin{array}{l}\text { Joints with } \\
\text { arthrosis }\end{array}$} & 3 carpal & 4 & 3 st.br. & $4-6$ yrs & $<\begin{array}{l}1 \mathrm{~m} \\
2 \mathrm{f}\end{array}$ \\
\hline & 2 tibiotarsal & & 1 cr.pony & 6 yrs & m \\
\hline
\end{tabular}

Osteochondrosis dissecans gave rise to an isoenzyme pattern similar to that of synovitis, but $\mathrm{LDH}_{5}$ was present in three cases out of 11 (Fig. 1). The total LDH activity was elevated, mean value being $291 \mathrm{u} / 1$, range $141-799$. The increase was found in $\mathrm{LDH}_{1}, \mathrm{LDH}_{2}, \mathrm{LDH}_{3}, \mathrm{LDH}_{4}$ and in three joints in $\mathrm{LDH}_{5}$ as well (Table 2).

The synovial fluids from the joints with a $r$ th ros is had a mean LDH activity of $739 \mathrm{u} / \mathrm{l}$, range $379-1522$. On fractionating the isoenzymes all five $\mathrm{LDH}$ isoenzymes were deeply stained and increased. The striking increase of $\mathrm{LDH}_{4}$ and the demonstration of $\mathrm{LDH}_{5}$ was thus a pronounced alteration (Fig. 1, Table 2).

No statistically significant correlation was found between the number of WBC and total LDH activity. 


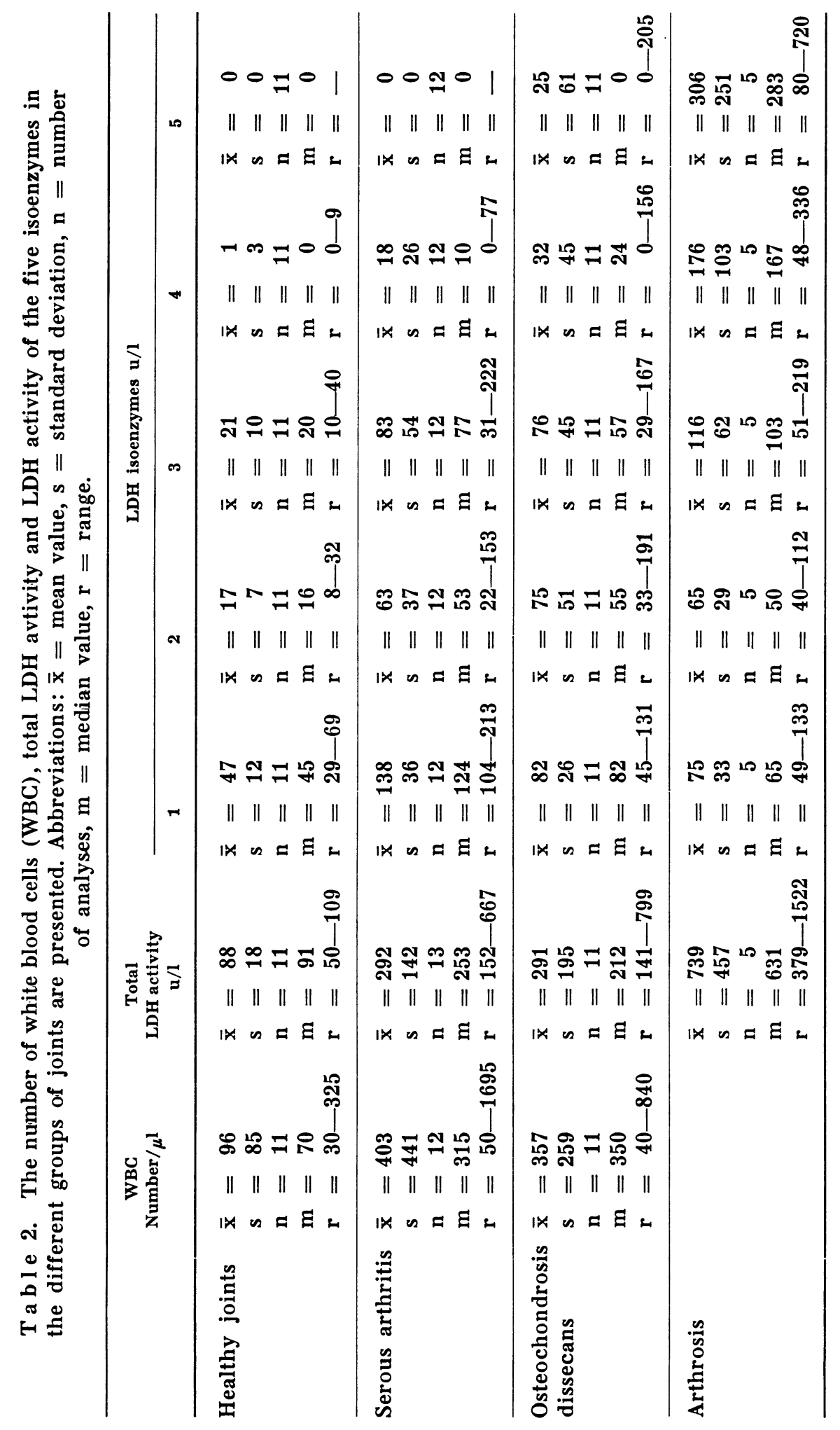


T a b l e 3. Mean values in per cent of total LDH activity of each isoenzyme are given for blood plasma, white blood cells (WBC), red blood cells $(\mathrm{RBC})$, synovial membrane and articular cartilage, $\mathrm{n}=$ number of analyses.

\begin{tabular}{lccccc}
\hline & \multicolumn{5}{c}{ Mean value \% of total LDH } \\
\cline { 2 - 6 } & $\begin{array}{c}\text { Plasma } \\
(\mathrm{n}=2)\end{array}$ & $\begin{array}{c}\text { WBC } \\
(\mathrm{n}=4)\end{array}$ & $\begin{array}{c}\text { RBC } \\
(\mathrm{n}=4)\end{array}$ & $\begin{array}{c}\text { synovial } \\
\text { membrane } \\
(\mathrm{n}=5)\end{array}$ & $\begin{array}{c}\text { articular } \\
\text { carticulage } \\
(\mathbf{n}=5)\end{array}$ \\
\hline $\mathrm{LDH}_{1}$ & 18 & 0 & 71 & 0 & 0 \\
$\mathrm{LDH}_{2}$ & 27 & 9 & 29 & 11 & 1 \\
$\mathrm{LDH}_{3}$ & 43 & 38 & 0 & 48 & 29 \\
$\mathrm{LDH}_{4}$ & 11 & 37 & 0 & 38 & 48 \\
$\mathrm{LDH}_{5}$ & 1 & 16 & 0 & 3 & 22 \\
\hline
\end{tabular}

\section{DISCUSSION}

In the present investigation it was shown that normal synovial fluid had a relatively low LDH activity. The laboratory where the present analyses of total $\mathrm{LDH}$ were performed has proposed $1300 \mathrm{u} / \mathrm{l}$ as the upper normal limit for horse serum total LDH activity with the method used in this investigation. The LDH activity of synovial fluid was increased in diseased joints compared to normal joints. This is true even for such mild inflammatory conditions as serous arthritis. Synovial fluid from healthy joints and from joints with the investigated joint diseases showed characteristic differences in their LDH isoenzyme patterns. Similarly, blood cells, blood plasma and articular tissues from normal horses each had characteristic LDH isoenzyme patterns. The results are in general agreement with those described in other species, the only exception being synovial tissue. Alexandersson et al. (1968) and Veys \& Wieme (1968) stated that synovial tissue is rich in $\mathrm{LDH}_{5}$. The present material showed only minimal content of $\mathrm{LDH}_{5}$ in synovial tissue. An explanation of this discrepancy could be the fact that the synovial tissue of the present material was taken from healthy joints, while the authors referred to above only examined synovial tissue from diseased joints. In a subsequent investigation it has been found that equine synovial tissue from joints with severe inflammation contains large amounts of $\mathrm{LDH}_{5}$ (Rejnö, work in progress).

The source of the increased amounts of LDH isoenzymes of synovial fluid in joint disease has been discussed in the literature. 
Tushan et al. (1969) showed that articular cartilage from cow, rabbit and man contained mainly $\mathrm{LDH}_{4}$ and $\mathrm{LDH}_{5}$. These LDH isoenzymes are regarded as facilitators of anaerobic glycolysis, thus supporting the opinion that anaerobic metabolism is the major pathway for energy generation in articular cartilage. Alexandersson et al. as well as Veys \& Wieme compared the number of WBC and the LDH activity in synovial fluid. No significant correlation between number of WBC and LDH activity was observed. The same observation was made in the present investigation. Perhaps the cells in the synovial fluid are still viable when the samples are centrifuged, so that their enzyme content remains mainly intracellular and does not interfere significantly with the isoenzyme patterns of the fluids.

The present results indicate that the increased levels of different $\mathrm{LDH}$ isoenzymes in synovial fluid from cases of serous arthritis and osteochondrosis dissecans originate from synovial tissue and/or white blood cells. Degenerative changes in the articular cartilage are not present in cases of uncomplicated synovitis. In osteochondrosis dissecans there are mainly proliferative or reparative processes in the cartilage and $\mathrm{LDH}_{5}$ is elevated only in joints with extensive cartilage lesions. Synovial fluid from joints with arthrosis, where degenerative cartilage changes are prominent, shows an elevation of all five LDH isoenzymes, and particularly $\mathrm{LDH}_{3}, \mathrm{LDH}_{4}$ and $\mathrm{LDH}_{5}$. These have been shown to be present in articular cartilage. It is therefore likely that the increased amount of synovial fluid LDH isoenzymes in cases of arthrosis originate from both synovial tissue and articular (artilage, the cathodal LDH isoenzymes giving the synovial fluid of degenerative joint disease a specific character. The results from one horse support this theory as both one healthy joint and two joints with arthrosis were investigated. The difference between the healthy joint and the diseased joints was striking, thus showing that the differences occur not only between animals, but also between joints in the same individual.

The results of the present study indicate that LDH and LDH isoenzyme analyses of equine synovial fluid could be valuable aids in clinical diagnosis of joint disease. With the methods described in this paper it should be possible to differentiate between joint diseases with or without degenerative cartilage lesions. However, it should be born in mind that in the present study only 
five joints with arthrosis were investigated. Further studies would therefore be necessary before the method could be used as routine method on analyzing synovial fluid from lame horses.

\section{REFERENCES}

Alexandersson, R., E. Nettelbladt \& L. Sundblad: Lactic dehydrogenase isoenzyme in arthritic synovial fluid: Effect of cortisol. Acta rheum. scand. 1968, 13, 243-252.

Barthel, C. H., J. R. Duncan \& R. F. Ross: Lactic dehydrogenase activity in plasma and synovial fluid of normal and mycoplasma hyorhinis infected swine. Amer. J. vet. Res. 1971, 32, 20112019.

Cohen, A. S.: Lactic dehydrogenase (LDH) and transaminase (GOT) activity of synovial fluid and serum in rheumatic disease states, with a note on synovial fluid LDH isoenzymes. Arthr. and Rheum. 1964, 7; 490-501.

Henry, R. J., D. C. Cannon \& J. W. Winkelman: Clinical Chemistry. Principles and Technics, 2nd Ed. 1974, 815-837. Harper \& Row Publishers Inc, Hagerstown, Maryland.

Hyldgaard-Jensen, J. F.: Lactate dehydrogenase in pigs. Studies of lactate dehydrogenase isoenzymes in blood and organs. Thesis. Munksgaard, Copenhagen 1971.

Lindy, S., H. Turto, J. Uitto \& K. Vainio: Origin of synovial fluid lactate dehydrogenase in rheumatoid arthritis. Clin. chim. Acta 1971, 35, 377-382.

Rejnö, S.: Work in progress.

Scandinavian Committee on Enzymes: Recommended methods for the determination of four enzymes in blood. Scand. J. clin. Lab. Invest. 1974, 33, 291.

Strömberg, B. \& S. Rejnö: Osteochondrosis in the horse. I. A clinical and radiologic investigation of Osteochondritis dissecans of the knee and hock joint. Accepted for publication in Acta radiologica 1976.

Tushan, F. S., G. P. Rodnan, M. Altman \& E. D. Robin: Anaerobic glycolysis and lactate dehydrogenase (LDH) isoenzymes in articular cartilage. J. Lab. clin. Med. 1969, 73, 649-656.

Vesell, E. S., K. C. Osterland, A. G. Bearn \& H. G. Kunkel: Isoenzymes of lactic dehydrogenase; their alterations in arthritic synovial fluid and sera. J. clin. Invest. 1962, 41, $2012-2019$.

Veys, E. M. \& R. J. Wieme: Lactate dehydrogenase in synovial fluid. Diagnostic evaluation of total activity and isoenzyme patterns. Ann. rheum. Dis. 1968, 27, 569-576.

Wegner, G. \& R. Mühlback: Der Wert der Papierelektrophorese und der LDH-Bestimmung als Hilfsmittel bei der Differenzierung von Kniegelenksergüssen. (The value of paper electrophoresis and LDH-determination as aids in differentiating knee joint effusions). Beitr. Orthop. Traum. 1971, 18, 21-23.

Wieme, R. J.: Agar Gel Electrophoresis. Elsevier, Amsterdam 1965. 


\section{SAMMANFATTNING}

LDH och LDH-isoenzymer $i$ hästsynovia.

I föreliggande artikel redovisas undersökningar av total LDHaktivitet och LDH-isoenzym-fördelning i hästsynovia från friska leder, leder med serös artrit, osteochondrosis dissecans och artros. Synovia från de sjuka lederna skilde sig från normal synovia genom förhöjd total LDH-aktivitet, och de olika ledsjukdomarna tycktes var och en karaktäriseras av ett speciellt isoenzym-mönster. För att undersöka möjliga källor till de ökade LDH-aktiviterna och de ändrade isoenzymmönstren, undersöktes också blodplasma, röda och vita blodkroppar, synovialmembran och ledbrosk. $\mathrm{LDH}_{4}$ och $\mathrm{LDH}_{5}$ befanns förekomma i höga halter i ledbrosk, och ökningar i halterna av dessa båda isoenzymer var den mest iögonenfallande förändringen i synovia från artrosleder.

(Received February 23, 1976).

Reprints may be requested from: Sven Rejnö, Department of Surgery, Royal Veterinary College, Fack, S-104 05 Stockholm 50, Sweden. 